\title{
Activation of Silent Synapses by Rapid Activity-Dependent Synaptic Recruitment of AMPA Receptors
}

\author{
Dezhi Liao, Robert H. Scannevin, and Richard Huganir \\ Department of Neuroscience, Howard Hughes Medical Institute, Johns Hopkins University School of Medicine, Baltimore, \\ Maryland 21205
}

\begin{abstract}
Many recent studies have shown that excitatory synapses can contain NMDA receptor responses in the absence of functional AMPA receptors and are therefore postsynaptically silent at resting membrane potentials. The activation of silent synapses via the rapid acquisition of AMPA receptor responses may be important in synaptic plasticity and neuronal development. Our recent immunocytochemical studies that used cultured hippocampal neurons have provided evidence for "morphological silent synapses" that physically contain NMDA receptors but no AMPA receptors. Here we show that the activation of NMDA receptors by spontaneous synaptic activity results in the rapid recruitment of AMPA receptors into these morphological silent
\end{abstract}

synapses within minutes. In parallel, we find a significant increase in the frequency of AMPA receptor-mediated miniature EPSCs (mEPSCs). NMDA receptor activation also results in a mobilization of calcium/calmodulin (CaM) kinase II to synapses and an increase in the phosphorylation of surface AMPA receptors on the major CaM kinase II phosphorylation site. These results demonstrate that AMPA receptors can be modified and recruited rapidly to silent synapses via the activation of NMDA receptors by spontaneous synaptic activity.

Key words: long-term potentiation; long-term depression; synaptic plasticity; GluR1; calcium/calmodulin-dependent protein kinase II; mEPSC
In the CNS the majority of excitatory synaptic transmission occurs at glutamatergic synapses and is mediated via the AMPA-, NMDA-, and kainate-type glutamate receptors (Hollmann and Heinemann, 1994). Models of synaptic plasticity, such as longterm potentiation (LTP) and long-term depression (LTD) of glutamatergic synapses, are believed to underlie the cellular basis of learning and memory in the adult brain and the activitydependent regulation of synapse formation in developing brain (Bliss and Collingridge, 1993; Malenka, 1994; Katz and Shatz, 1996). The molecular mechanism of such synaptic plasticity, however, is not known. Current evidence suggests that activitydependent changes in synaptic strength, such as LTP and LTD, result at least in part from changes in AMPA receptor-mediated responses (Kauer et al., 1988; Muller et al., 1988; Davies et al., 1989; Liao et al., 1992). These changes may be attributable to altered levels of AMPA receptors in the postsynaptic membrane, altered receptor properties, or a combination of these two mechanisms.

It has been reported previously that AMPA receptors are phosphorylated and dephosphorylated during LTP and LTD, respectively, and that this may lead to changes in the ion channel conductance or open channel probability of AMPA receptors during these processes (Barria et al., 1997a; Benke et al., 1998; Lee et al., 1998, 2000; Derkach et al., 1999; Banke et al., 2000). Numerous recent studies suggest that the level of synaptic AMPA receptors also can be modulated by activity-dependent mecha-

\footnotetext{
Received March 28, 2001; revised May 14, 2001; accepted May 23, 2001.

This work was supported by the Howard Hughes Medical Institute and the National Institutes of Health. We thank Doreen Bury for assistance in preparing this manuscript.

Correspondence should be addressed to Dr. Richard L. Huganir, Department of Neuroscience, Howard Hughes Medical Institute, Johns Hopkins University School of Medicine, 725 North Wolfe Street, Baltimore, MD 21205. E-mail: rhuganir@jhmi.edu.

Copyright (C) 2001 Society for Neuroscience $\quad 0270-6474 / 01 / 216008-10 \$ 15.00 / 0$
}

nisms (Kim and Huganir, 1999; Turrigiano, 2000). Both electrophysiological and morphological studies have indicated that a significant fraction of glutamatergic synapses contains NMDA receptors without detectable AMPA receptors (Isaac et al., 1995; Liao et al., 1995, 1999; Durand et al., 1996; Nusser et al., 1998; Petralia et al., 1999). Such synapses would be postsynaptically silent under normal resting potentials because of the voltagedependent blockade of NMDA receptors by magnesium (Mayer et al., 1984; Nowak et al., 1984). Whole-cell recordings in brain slices demonstrate that such silent synapses can be activated via the acquisition of AMPA receptor-mediated responses after an LTP-inducing protocol that lasts only minutes (Isaac et al., 1995; Liao et al., 1995). The cellular mechanism underlying this rapid acquisition of AMPA receptor responses in silent synapses is not clear.

Several groups have reported that the chronic blockade of synaptic activity with CNQX or TTX for hours or days can cause a slow modulation in the amount of postsynaptic AMPA receptors in neuronal cultures (O'Brien et al., 1998; Turrigiano et al., 1998). It also has been reported that synaptic AMPA receptors in hippocampal cultures can be dispersed or internalized rapidly after a brief application of glutamate or an electrical LTD induction protocol (Lissin et al., 1998, 1999; Carroll et al., 1999). Moreover, it has been reported recently that recombinant green fluorescent protein-tagged (GFP-tagged) GluR1 subunits can be mobilized rapidly to dendritic spines within minutes after a burst of high-frequency stimuli in cultured hippocampal slices (Shi et al., 1999; Hayashi et al., 2000). However, there is no direct morphological evidence that activity can regulate rapidly the recruitment of native AMPA receptors into silent synapses.

In this paper we have analyzed the rapid NMDA receptor- and activity-dependent modulation of synaptic AMPA receptors in both low-density hippocampal cultures and high-density cortical cultures. These cultured neurons have a large number of morpho- 
logical silent synapses that contain clustered NMDA receptors but no detectable clustered AMPA receptors. Combining immunocytochemical and electrophysiological techniques, we demonstrate that these silent synapses rapidly become responsive to synaptically released glutamate via the recruitment of AMPA receptors after the activation of NMDA receptors.

\section{MATERIALS AND METHODS}

Neuronal cultures. Low-density hippocampal cultures from 18-d-old embryonic rats were prepared as reported previously (Banker and Cowan, 1977). Neurons were plated onto $60 \mathrm{~mm}$ Petri dishes (Becton Dickinson, Bedford, MA) at a density of $120,000-200,000$ cells per dish. Some dishes contained five coverslips per dish at a density of $1 \times 10^{6}$ cells per dish. In some cultures, D,L-aminophosphonovalerate (D,L-APV; $200 \mu \mathrm{M}$ ) was added to the culture medium to chronically block NMDA receptors at $5 \mathrm{~d}$ after plating.

High-density cortical cultures from 17- or 18-d-old embryonic rats were prepared as reported previously (Ghosh and Greenberg, 1995). Neurons were plated onto $60 \mathrm{~mm}$ Petri dishes (Becton Dickinson), with some dishes containing five coverslips per dish at a density of $6 \times 10^{6}$ cells per dish. Dishes that were used for biochemical experiments contained no coverslip. D,L-APV $(200 \mu \mathrm{M})$ was added into the culture medium at $4 \mathrm{~d}$ after plating, and the same concentration of D,L-APV was maintained until usage. Thereafter, the cortical neurons were fed twice per week with feeding medium that had been incubated with glial cells overnight.

Induction protocol for synaptic targeting of AMPA receptors. Highdensity cortical neurons chronically treated with $200 \mu \mathrm{M}$ D,L-APV were incubated in artificial CSF [aCSF; containing (in mM) $125 \mathrm{NaCl}, 2.5 \mathrm{KCl}$, $26.2 \mathrm{NaHCO}_{3}, 1 \mathrm{NaH}_{2} \mathrm{PO}_{4}, 11$ glucose, $2.5 \mathrm{CaCl}_{2}$, and $1.25 \mathrm{MgCl}_{2}$ at $37^{\circ} \mathrm{C}$ plus $5 \% \mathrm{CO}_{2}$ ] in a tissue culture chamber for $\sim 15-20 \mathrm{~min}$. Although sometimes an increase in the number of AMPA receptor clusters was observed after the withdrawal of D,L-APV for 5 min (data not shown), a more consistent change often was induced by a treatment for $\sim 15$ min. In control experiments, $200 \mu \mathrm{M}$ D,L-APV was added to aCSF to block the NMDA receptors.

Withdrawal of D,L-APV alone in low-density hippocampal cultures was unable to induce a rapid mobilization of AMPA receptors. Most likely the low-density cultures lack the high levels of spontaneous activity that are necessary to provide both sufficient postsynaptic depolarization and released glutamate for the activation of NMDA receptors. In another protocol to induce synaptic targeting of AMPA receptors, we added glycine to aCSF to enhance the NMDA receptor channel opening and removed $\mathrm{Mg}^{2+}$ to allow for the activation of NMDA receptors at hyperpolarizing potentials. Cultured neurons were incubated in aCSF containing $2.5 \mathrm{mM} \mathrm{Ca}{ }^{2+}, 100 \mu \mathrm{M}$ glycine, and no added $\mathrm{Mg}^{2+}$ in a tissue culture chamber for $\sim 15-20 \mathrm{~min}$. This protocol can induce a rapid mobilization of AMPA receptors in low-density hippocampal cultures growing in culture medium either with or without D,L-APV.

Immunocytochemistry. As described previously (Liao et al., 1999), cultured neurons were fixed successively with $4 \%$ paraformaldehyde, $4 \%$ sucrose in PBS $\left(4^{\circ} \mathrm{C}, 20 \mathrm{~min}\right)$, and then with $-20^{\circ} \mathrm{C}, 100 \%$ methanol (incubated at $4^{\circ} \mathrm{C}, \sim 10-15 \mathrm{~min}$ ); next the neurons were permeabilized with $0.2 \%$ Triton $\mathrm{X}-100\left(4^{\circ} \mathrm{C}, \sim 10-15 \mathrm{~min}\right)$. Coverslips with neurons were blocked in $10 \%$ donkey serum in PBS for $\sim 30-60 \mathrm{~min}$ and then incubated with primary antibodies dissolved in $10 \%$ donkey serum in PBS. All primary rabbit polyclonal antibodies were affinity-purified and conjugated either to $\mathrm{Cy} 3$ (red; Amersham Pharmacia Biotech, Arlington Heights, IL) or to Fluorescein-Ex (green; Molecular Probes, Eugene, OR). Mouse monoclonal primary antibodies were visualized with antimouse IgG antibodies linked to fluorescein isothiocyanate (FITC; green), rhodamine (red), or AMCA (blue; Jackson ImmunoResearch Laboratories, West Grove, PA).

Two rabbit polyclonal antibodies against the $\mathrm{C}$ terminus of the GluR1 subunit and the GluR 2/3 subunit, respectively, were used to detect AMPA receptor subunits. In most of the presented data the GluR1 and GluR2/3 antibodies were added together to detect AMPA receptors. A rabbit polyclonal antibody against the $\mathrm{N}$ terminus of the NMDA receptor 1 (NR1) subunit was used to detect this obligatory subunit of functional NMDA receptors. A mouse monoclonal antibody (MAB3119, Chemicon, Temecula, CA) was used to detect the $\alpha$-isoform of calcium/calmodulin (CaM) kinase II (Erondu and Kennedy, 1985).

The visual field was moved blindly to a random site on a coverslip. In coverslips that were double-stained with antibodies against NR1 and AMPA receptor subunits, we first found and focused on a pyramidal neuron under the fluorescent channel that detected the NR1 staining. Thereafter, images of both NR1 subunits and AMPA receptor subunits were sampled by a digital camera (Princeton Instruments, Trenton, NJ) and analyzed with the MetaMorph Imaging System (Universal Imaging, West Chester, PA). In coverslips that were double-stained with synaptophysin and another antibody, the staining of synaptophysin was used for searching and focusing. Both NMDA and AMPA receptor clusters were significantly brighter than their surrounding areas. Almost all of them were marked as regions of interest by the computer when we set a threshold of fluorescent intensity that was slightly higher than the distant dendritic shafts but lower than cell body and proximal dendritic shafts. We included only those regions with an area $>5$ pixels and $<500$ pixels. The upper threshold limit for this selection was used to exclude the cell body and proximal dendritic shafts, which have much larger area than spines. We used a $100 \times$ objective to acquire our images $(1 \mu \mathrm{m}=15$ pixels; $1 \mu \mathrm{m}^{2}=225$ pixels). Most of the clusters were $<1 \mu \mathrm{m}^{2}$ because the peripheral area of the selected cluster was not included. All regions of interest marked by the computer were compared with clusters that had been identified visually by the experimenter. Poor images without sharp NMDA receptor clusters and AMPA receptor clusters were discarded. Synaptophysin and CaM kinase II clusters are not sharp enough to be counted with this method. In the high-density neuronal cultures we were not able to trace dendrites and to normalize the number of receptor clusters to dendritic length. However, we have found that the density of synapses is similar between coverslips in sister cultures and is distributed randomly on the coverslip, allowing us to analyze the number of clusters per field and reliably compare the number of receptor clusters between culture dishes. In low-density hippocampal cultures the number of receptor clusters was normalized with the dendritic length after all of the dendritic branches in an image were traced and measured manually.

Immunoblotting and biotinylation of surface proteins. Cortical neurons were grown as described in the presence of D,L-APV for 3-4 weeks and were subjected to the described induction protocol. After induction all of the dishes were cooled on ice and washed two times with ice-cold aCSF. Cultures then were incubated with aCSF containing $1 \mathrm{mg} / \mathrm{ml}$ sulfo-NHSLC-biotin (Pierce Chemical, Rockford, IL) for $20 \mathrm{~min}$ on ice. Unreacted biotinylation reagent was quenched by three successive 5 min washes in ice-cold TBS (50 mM Tris pH 7.5, $150 \mathrm{~mm} \mathrm{NaCl)}$. Cultures were lysed in modified RIPA buffer [1\% Triton X-100, $0.1 \%$ SDS, $0.5 \%$ deoxycholic acid and (in mM) $10 \mathrm{NaPO}_{4}, 150 \mathrm{NaCl}, 2$ EDTA, $50 \mathrm{NaF}, 10$ sodium pyrophosphate, 10 iodoacetamide, 1 sodium orthovanadate, and 1 phenylmethylsulfonyl fluoride plus (in $\mu \mathrm{g} / \mathrm{ml}$ ) 2 aprotinin, 1 leupeptin, 2 antipain, and 10 benzamide] on ice and then harvested with a cell scraper. Crude lysates were cleared by centrifugation at $14,000 \times g$ for 15 $\min$ at $4^{\circ} \mathrm{C}$. A portion of the supernatant was added to SDS sample buffer for use as the total input for each sample. The remaining supernatant was diluted to a final volume of $1 \mathrm{ml}$ in RIPA buffer. Then $100 \mu \mathrm{l}$ of $50 \%$ NeutrAvidin agarose (Pierce Chemical) was added, and the samples were rotated for $3 \mathrm{hr}$ at $4^{\circ} \mathrm{C}$. Next the NeutrAvidin agarose was washed five times with RIPA buffer, and the bound proteins were eluted into SDS sample buffer by boiling for $15 \mathrm{~min}$. Total protein and isolated biotinylated proteins were fractionated by SDS-PAGE and electroblotted onto Immobilon-P membrane (Millipore, Bedford, MA). Membranes were immunoblotted with affinity-purified antibodies against either GluR1 AMPA receptor subunits or the phosphorylation site-specific antibody against phosphorylated S831 of the GluR1 subunit (Roche et al., 1996; Mammen et al., 1997). All immunoblots were visualized by ECL development (Amersham Pharmacia Biotech) and quantified on a Storm Imaging System (Molecular Dynamics, Sunnyvale, CA). Surface expression was determined by calculating the ratio of the cell surface signal (signal from NeutrAvidin pull-down lane/percentage of total pull-down loaded on gel) and dividing this by the total input (signal in total input lane/percentage of total input loaded on gel) for each sample. For all experiments the input and pull-down samples were loaded on the same gels to minimize variability in different immunoblots. Loading controls were performed in all experiments to verify the linearity of quantified signals. Reported data represent the mean $\pm \mathrm{SE}$ for the given number of dishes each for control and experimental groups harvested from four different dates of culture preparation.

Detection of phosphorylation of AMPA receptors. A phosphorylation site-specific antibody raised against a synthetic phosphopeptide (phosphorylated on serine 831) corresponding to the C terminus of GluR1 (GluR1-S831-P) has been well characterized previously (Roche et al., 1996; Mammen et al., 1997). This antibody was used for quantitative immunoblot analysis of total extract and cell surface proteins. Then the 
A

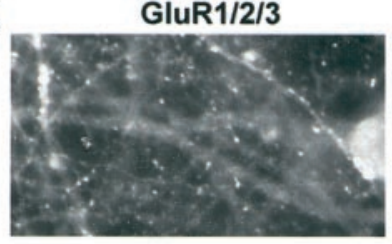

C

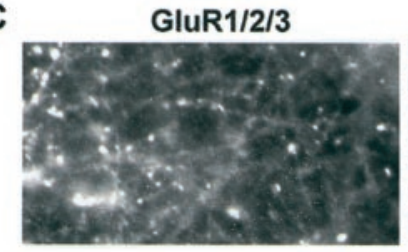

E

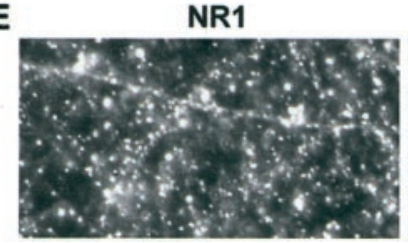

NR1

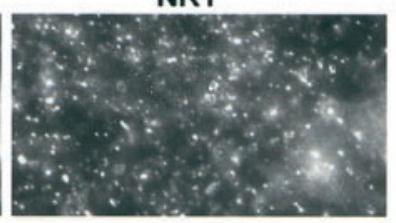

Synaptophysin

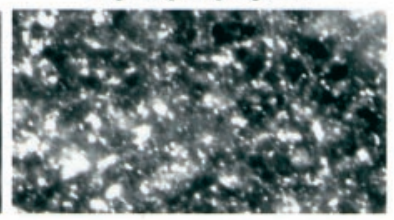

Synaptophysin

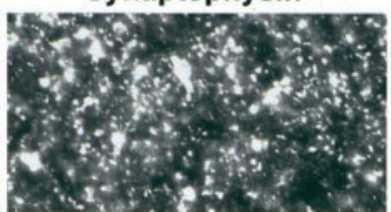

B

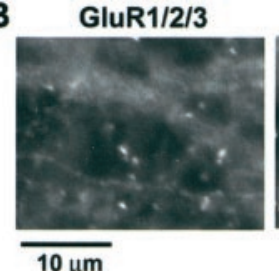

D

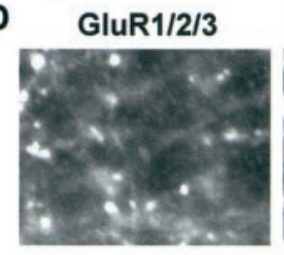

F

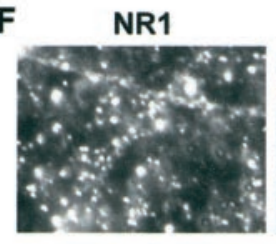

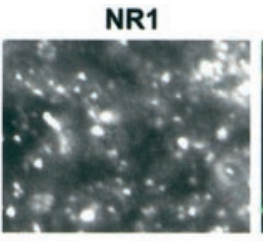

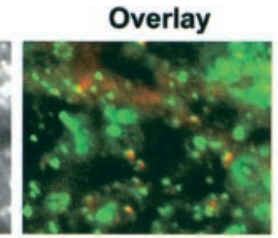

Synaptophysin
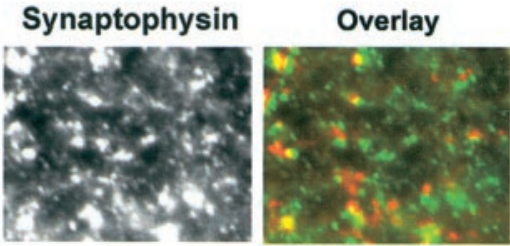

Synaptophysin

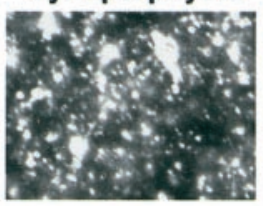

Overlay

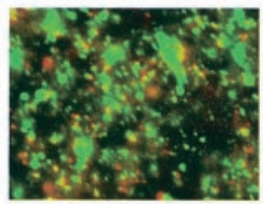

Figure 1. Many morphological silent synapses exist in high-density cultured cortical neurons chronically treated with D,L-APV. $A$, Double staining of high-density cultured cortical neurons by antibodies against AMPA receptor subunits (GluR1/2/3, left) and an NMDA receptor subunit (NR1, right). $B$, Enlarged images $(2 \times)$ from $A$ [left, GluR1/2/3; middle, NR1; right, overlay of GluR1+GluR2 (red) and NR1 (green)]. Scale bar: $B, D, F, 10 \mu \mathrm{m} . C$, Double staining of AMPA receptor subunits (GluR1/2/3, left) and synaptophysin (right). $D$, Enlarged images $(2 \times)$ from $C$ [left, GluR1+GluR2; middle, synaptophysin; right, overlay of GluR1+GluR2 (red) and synaptophysin (green)]. E, Double staining of NMDA receptor subunit (NR1, left) and synaptophysin (right). F, Enlarged images $(2 \times)$ from $E$ [left, NR1; middle, synaptophysin; right, overlay of NR1 (red) and synaptophysin ( green)].

levels of GluR1-S831-P were compared with the respective levels of total GluR1 to determine the relative amount of the subunit population that was phosphorylated.

Electrophysiology. Whole-cell voltage-clamp recordings were established in high-density cortical neurons with a holding potential at -55 to $-60 \mathrm{mV}$ in aCSF $\left(\right.$ at $\left.32^{\circ} \mathrm{C}, 95 \% \mathrm{O}_{2} / 5 \% \mathrm{CO}_{2}\right)$ with $200 \mu \mathrm{M}$ D,L-APV, 1

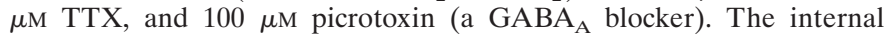
solution in the patch electrode contained (in mM) 100 cesium gluconate, 40 HEPES, 2 Na-ATP, 0.3 GTP, $5 \mathrm{MgCl}_{2}, 5$ glutathione, and 0.2 EGTA, $\mathrm{pH}$-adjusted to 7.2 with $\mathrm{CsOH}$. All recordings were filtered at $2 \mathrm{kHz}$. Series and input resistance was checked every $5 \mathrm{sec}$. Experiments with a series resistance $>20 \mathrm{M} \Omega$ or with a change of series or input resistance $>15 \%$ were discarded. There was no significant difference in the series resistances recorded at neurons with or without the withdrawal of D,L$\operatorname{APV}(5.9 \pm 0.8$ vs $5.8 \pm 0.6 \mathrm{M} \Omega ; p>0.05)$ and also no difference in input resistance $(220.5 \pm 75$ vs $248.3 \pm 25 \mathrm{M} \Omega ; p>0.05)$. The resting potential was slightly more negative than the holding potential $(-55$ to $-60 \mathrm{mV})$ because the holding current was 0 to $+20 \mathrm{pA}$ at the moment when the plasma membrane was broken through. One recording sweep lasting 200 msec was sampled for every $1 \mathrm{sec}$. Detection criteria for miniature EPSCs (mEPSCs) included peak amplitudes $>3 \mathrm{pA}$ and a fast rise time and a slow decay time. A typical recording lasted $\sim 20-30 \mathrm{~min}$. The starting point, the peak, and the ending point of a mEPSC were identified visually. The rise time was measured as the distance between the starting point and the peak. The decay time was measured as the distance between the ending point and the peak. To minimize variability in the density and maturation of recorded cortical neurons, we performed equal numbers of testing and control experiments in neurons from the same batch of cultures each day.

Data analysis. All data are reported as mean \pm SE. Sample size $n$ refers to the number of images processed in immunocytochemistry, the number of neurons in whole-cell recordings, and the number of dishes analyzed in biotinylation experiments. Group $t$ test was used to test the difference between the control and testing groups, and ANOVA was used to compare differences among several groups; ${ }^{*} p<0.05$, ${ }^{* *} p<0.01$, and *** $p<0.001$.

\section{RESULTS}

We have shown previously that low-density hippocampal cultures contain many "morphological silent synapses," synapses that con- tain NMDA receptors but no AMPA receptors, and that the proportion of these silent synapses can be increased by chronic treatment with the NMDA receptor antagonist D,L-APV (Liao et al., 1999). In these previous studies, however, we were unable to obtain rapid activity-dependent changes in AMPA receptor distribution, possibly because of a low level of spontaneous activity in these cultures. To circumvent this problem, we examined AMPA receptor targeting by using high-density cortical neuronal cultures that have much higher levels of spontaneous activity (Murphy et al., 1992). To maximize the number of silent synapses in the cortical cultures, we maintained them in NMDA receptor antagonists (Liao et al., 1999). Then the distribution of glutamate receptors in the cultured cortical neurons (23-26 DIV) was analyzed with the use of AMPA and NMDA receptor antibodies. The neurons were fixed, permeabilized, and double-labeled with a NMDA receptor NR1 subunit antibody directly coupled to FITC (green) and with GluR1 and GluR2/3 AMPA receptor subunit antibodies directly coupled to $\mathrm{Cy} 3$ (red). The cortical neurons contained a dense network of neurites with a high density of NMDA receptor clusters (Fig. $1 A, B$ ). In contrast, the neurons had a diffuse distribution of AMPA receptors in the dendrites and contained few clusters of AMPA receptors (Fig. $1 A, B)$. The relatively few AMPA receptor clusters colocalized $(>95 \%)$ with the NMDA receptor clusters (Fig. $1 A, B$ ); however, most of the NMDA receptor clusters $(55.7 \% \pm 3 \% ; n=20)$ did not contain colocalized AMPA receptor clusters. The immunocytochemical labeling of both the diffuse and clustered receptors was blocked specifically by preincubation of the antibodies with the appropriate antigen (data not shown). To examine whether these receptor clusters were synaptic, we double-labeled the neurons with antibodies against NMDA or AMPA receptors and an antibody to the synaptic marker synaptophysin (Fig. $1 C-F$ ). Similar to low-density hippocampal cultures (Liao et al., 1999), $>90 \%$ 

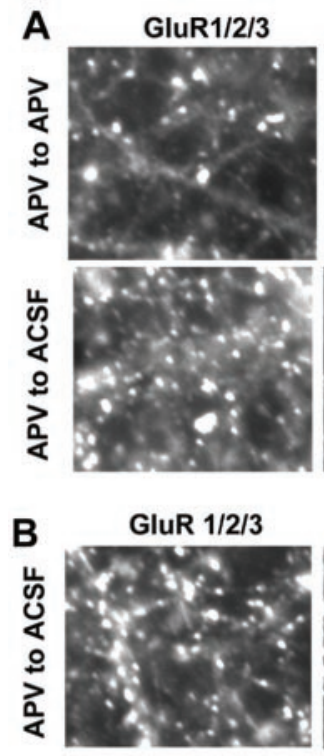

$10 \mu \mathrm{m}$

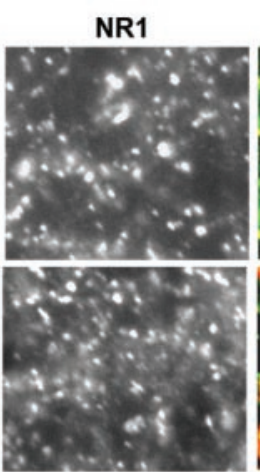

Synaptophysin

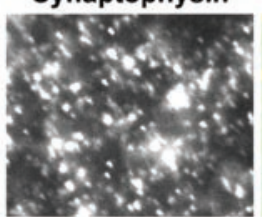

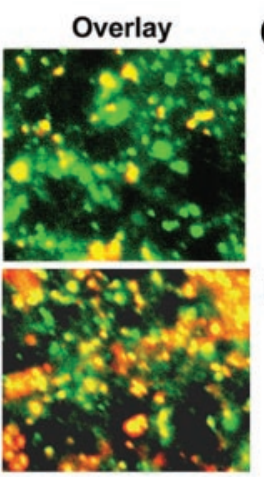

Overlay

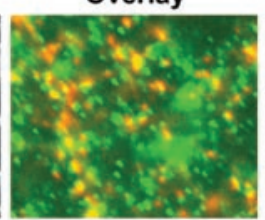

C

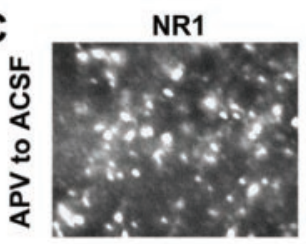

D

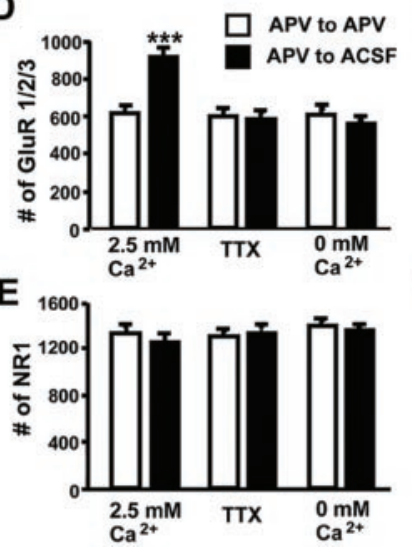

Synaptophysin
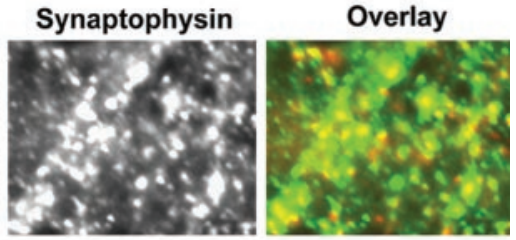

$\mathbf{F}$

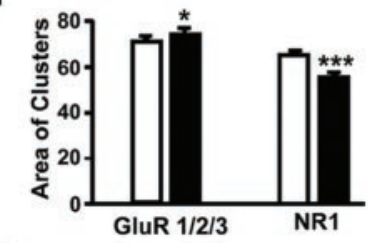

$\mathbf{G}$

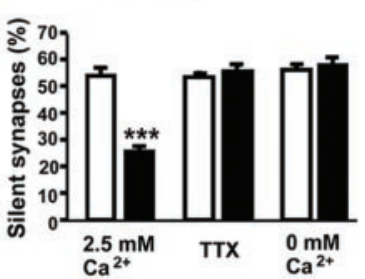

Figure 2. Mobilization of AMPA receptors into silent synapses via the activation of NMDA receptors by spontaneous synaptic activity. $A$, Double staining of high-density cultured cortical neurons by antibodies against AMPA receptor subunits (left, GluR1/2/3) and an NMDA receptor subunit (middle, NR1) after the neurons were incubated in aCSF in the presence (top panels) and absence (bottom panels) of D,L-APV. Right panels are overlays of the left and middle panels (GluR1/2/3, red; NR1, green). B, Double staining of high-density cultured cortical neurons by antibodies against AMPA receptor subunits (GluR1/2/3, red) and synaptophysin ( green) after the withdrawal of D,L-APV. C, Double staining of NR1 (red) and synaptophysin ( green) after the withdrawal of D,L-APV. Scale bar: $A-C, 10 \mu \mathrm{m} . D$, The number of AMPA receptor clusters (GluR1 and GluR2/3) is increased significantly after the withdrawal of D,L-APV ( filled bars) compared with control (open bars; neurons incubated in aCSF with D,L-APV). TTX and 0 mM $\mathrm{Ca}^{2+}$ blocked this increase. $E$, Withdrawal of D,L-APV had a negligible effect on the number of NR1 clusters. $F$, The effect of withdrawal of D,L-APV on the apparent size of AMPA receptor clusters and NR1 clusters. G, The proportion of silent synapses was decreased significantly after the withdrawal of D,L-APV ( filled bars) compared with control (open bars). Silent synapses refer to synapses that contain only clustered N R1 receptors but no clustered AMPA receptors (GluR1 and GluR2/3). ${ }^{*} p<0.05 ;{ }^{* *} p<0.001$.

of the receptor clusters colocalized with, or juxtaposed to, synaptophysin immunostaining, indicating that they are synaptic. These results demonstrate that, as with the low-density hippocampal cultures, many excitatory synapses in these high-density cortical cultures are "morphologically silent" and contain clustered NMDA receptors but no colocalized clustered AMPA receptors.

Despite the large number of "silent synapses" in these cultures, whole-cell recordings of the cortical neurons showed a robust network activity (data not shown) with bursts of high-frequency spontaneous synaptic activity (with frequency $>100 \mathrm{~Hz}$; duration $\sim 5-10 \mathrm{sec}$ ). We hypothesized that this activity might be able to trigger rapid NMDA receptor-dependent recruitment of functional AMPA receptors into silent synapses. To test this idea, we removed the D,L-APV from the chronically treated cortical neurons and then fixed the neurons 15-20 min later. Control neurons were maintained in D,L-APV. The neurons were fixed, permeabilized, and labeled with both GluR1 and GluR2/3 antibodies to analyze the AMPA receptor distribution. As discussed above, the cultures maintained in the presence of D,L-APV contained a large number of dendrites that had a diffuse distribution of AMPA receptors and contained few synaptic clusters of AMPA receptors (Fig. $2 A$, top panels). This was in stark contrast to cultures that had the D,L-APV removed, in which the AMPA receptors had been redistributed rapidly within the dendrites, forming clusters (Fig. $2 A$, bottom panels). In a quantitative analysis we found that the withdrawal of D,L-APV significantly increased the number of AMPA receptor clusters by $49 \%$ (from $622 \pm 36$ to $926 \pm 26$ per field; $p<0.001 ; n 1=20, n 2=20$; Fig. $2 D$ ). No significant change was observed in the number of NR1 receptor clusters (from $1340 \pm 50$ to $1261 \pm 38$ per field; $p>0.05 ; n 1=20, n 2=20$; Fig. $2 E$ ). Similar to the control, we found that $>95 \%$ of AMPA receptor clusters were colocalized with NR1 clusters after D,LAPV removal (Fig. 2A, bottom panels). We estimated the proportion of silent synapses by analyzing the percentage of NR1 clusters that were not colocalized with AMPA receptors. After the withdrawal of D,L-AP the proportion of silent synapses significantly decreased from 54.1 to $26.2 \%$ ( $p<0.001$; Fig. 2G). Withdrawal of D,L-APV had no significant effect on the fluorescent intensity of either NMDA clusters or AMPA receptor clusters; however, we noticed a significant decrease in the apparent size of NR1 clusters after the withdrawal of D,L-APV (from 68.9 to 57.5 pixels; $p<0.001 ; 1 \mu \mathrm{m}=15$ pixels, $1 \mu \mathrm{m}^{2}=225$ pixels; Fig. $2 G$ ) and a small increase in the apparent size of AMPA receptor clusters (from 71 to 75 pixels; $p=0.049$; Fig. $2 F$ ).

To test whether these new AMPA receptor clusters were truly synaptic, we double-labeled 26- to 30-d-old high-density cortical neurons with antibodies against synaptophysin and AMPA receptor subunits (GluR1 plus GluR2/3) after incubation with or without D,L-APV for $\sim 15-20 \mathrm{~min}$. As shown in Figure $2 B$, almost all of the AMPA receptor clusters were colocalized or adjacent to a synaptophysin cluster after the withdrawal of D,L-APV. In another set of experiments the cultures were double-stained with an anti-synaptophysin and an anti-NR1 antibody after incubation with or without D,L-APV. Similar to AMPA receptors, $>95 \%$ of the NR1 clusters were colocalized or juxtaposed to synaptophysin staining after the withdrawal of D,L-APV (Fig. $2 C$ ). To examine whether the synaptic recruitment of AMPA receptors is attribut- 
able to the activation of NMDA receptors by the observed highfrequency spontaneous synaptic responses, we used TTX to block sodium channel-mediated action potentials. In the presence of TTX the withdrawal of D,L-APV had no significant effect on the number of AMPA receptor clusters (from $607 \pm 29$ to $591 \pm 32$ per field; $p>0.05 ; n 1=20, n 2=20$; Fig. $2 D$ ) or NMDA receptor clusters (from $1310 \pm 45$ to $1340 \pm 48$ per field; $p>0.05 ; n 1=$ $20, n 2=20$; Fig. $2 E$ ) and the proportion of silent synapses (from 53.6 to $55.8 \% ; p>0.05$; Fig. $2 G$ ). To test further whether the mobilization of AMPA receptors was dependent on synaptic activity, we removed $\mathrm{Ca}^{2+}$ from the aCSF bath solution to block the release of presynaptic vesicles. In aCSF with $0 \mathrm{mM} \mathrm{Ca}^{2+}$ the withdrawal of D,L-APV did not affect the number of AMPA receptor clusters significantly (from $611 \pm 31$ to $565 \pm 25$ per field; $p>0.05 ; n 1=20, n 2=20$; Fig. $2 D$ ) or NMDA receptor clusters (from $1402 \pm 44$ to $1361 \pm 36$ per field; $p>0.05 ; n 1=$ $20, n 2=20$; Fig. $2 E$ ) or the number of silent synapses (from 56.6 to $58.4 \%$; $p>0.05$; Fig. $2 G$ ). These results indicate that activation of NMDA receptors can induce a rapid mobilization of AMPA receptors into morphological silent synapses that previously contained only NMDA receptors but no AMPA receptors.

We next wanted to determine whether the new synaptic AMPA receptor clusters were present on the cell surface. Using the same induction protocol, we labeled the surface GluR1 receptors on live neurons with an antibody against the $\mathrm{N}$ terminus of GluR1. Withdrawal of D,L-APV significantly increased the number of surface GluR1 clusters (from $672 \pm 45$ to $976 \pm 37$ per field; $p<$ $0.001 ; n 1=20, n 2=20$; Fig. $3 A, B)$ but had no significant effect on the number of NR1 clusters (from $1330 \pm 43$ to $1328 \pm 38$ per field; $p>0.05 ; n 1=20, n 2=20$; Fig. $3 A, B)$. The proportion of morphological silent synapses significantly decreased from 50.2 to $26 \%(p<0.001$; Fig. $3 B)$.

LTP induction results in the long-lasting increases in AMPA receptor responses. To examine whether the synaptic recruitment of AMPA receptors in our system is a long-term effect, we removed D,L-APV from the neurons for $15 \mathrm{~min}$ and then placed them back into culture medium containing D,L-APV for $2 \mathrm{hr}$. Under these conditions we observed a persistent increase in the number of AMPA receptor clusters (from $434 \pm 18$ to $685 \pm 19$ per field; $p<0.001 ; n 1=20, n 2=20$; Fig. $4 A, B)$ and a persistent decrease in the amount of silent synapses (from 65 to $46 \%$; $p<$ 0.001 ; Fig. $4 A, B)$.

To rule out that the mobilization of AMPA receptors was induced directly by action potentials via NMDA receptorindependent pathways, we added TTX to the aCSF bath solution to block action potentials and then removed D,L-APV and $\mathrm{Mg}^{2+}$ in the presence of exogenous glycine to allow for the activation of NMDA receptors by the spontaneous release of glutamate. Although not as dramatic, under this condition the withdrawal of D,L-APV also significantly increased the number of AMPA receptor clusters (from $468 \pm 26$ to $592 \pm 15$ per field; $p<0.001$; $n 1=20, n 2=20$; Fig. $5 A, B)$, had no effect on the number of NR1 clusters (from $1167 \pm 36$ to $1116 \pm 29$ per field; $p>0.05 ; n 1=$ $20, n 2=20$; Fig. $5 A, B)$, and decreased the number of silent synapses significantly from 59.8 to $46.7 \%$ ( $p<0.001$; Fig. $5 B)$.

Interestingly, a similar protocol also could be used to recruit rapidly the AMPA receptors in low-density hippocampal cultures despite the low intrinsic activity in these cultures. As with the TTX-treated cortical cultures, the activation of NMDA receptors in the low-density hippocampal cultures by D,L-APV and $\mathrm{Mg}^{2+}$ removal in the presence of exogenous glycine increased the number of AMPA receptor clusters (from $29.7 \pm 3.3$ to $88.8 \pm 8.0 / 100$
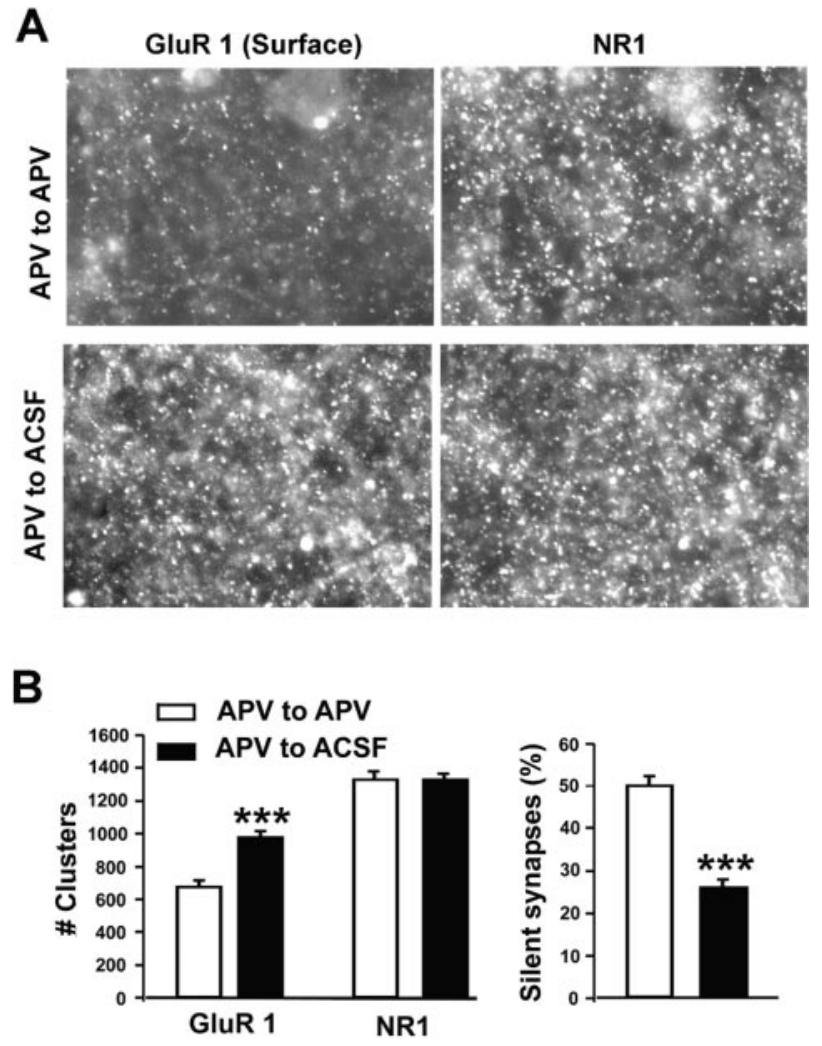

Figure 3. GluR1 AMPA receptor subunits were mobilized to the synaptic surface after the withdrawal of D,L-APV. $A$, Double staining of high-density cultured cortical neurons by antibodies against the $\mathrm{N}$ terminus of surface GluR1 subunits (left) and the C terminus of NR1 subunits (right) after these neurons were incubated in aCSF in the presence (top) and absence (bottom) of D,L-APV. B, The number of surface GluR1 clusters was increased (left) and the proportion of silent synapses was decreased (right) after the withdrawal of D,L-APV ( filled bars) compared with control (open bars). ***p $<0.001$.

$\mu \mathrm{m}$ of dendrite; $p<0.001 ; n 1=20, n 2=20$; Fig. $6 A, B)$ and reduced that number of silent synapses at hippocampal neurons from 73.8 to $23 \%$ (Fig. $6 C$ ). After this paradigm the silent synapses almost disappeared in one-half of the analyzed neurons, in which almost all of the AMPA clusters were colocalized with NR1 clusters ( $>90 \%$; Fig. $6 \mathrm{~A}$, bottom two panels). The recruitment of AMPA receptor to synapses also could be observed in the absence of chronic treatment of the neurons with D,L-APV. Although the initial proportion of silent synapses in cultures grown in normal medium was lower than the D,L-APV-treated cultures, the removal of $\mathrm{Mg}^{2+}$ in the presence of exogenous glycine increased the number of AMPA receptor clusters from $55.4 \pm 4.8$ to $98.6 \pm 7.3 / 100 \mu \mathrm{m}$ of dendrite $(p<0.001 ; n 1=20$, $n 2=20$; Fig. $6 E$ ) and decreased the proportion of silent synapses (from 53.4 to $18.2 \%$; Fig. $6 F$ ).

If the AMPA receptors delivered into silent synapses were functional, we would expect to see a parallel increase in mEPSC responses after the withdrawal of D,L-APV. We induced synaptic targeting of AMPA receptors by incubating cortical neurons with aCSF in the absence of D,L-APV for 15-20 min. Thereafter, mEPSC responses mediated via AMPA receptors were recorded in aCSF $\left[2.5 \mathrm{mM} \mathrm{Ca}^{2+}\right.$ and (in $\mu \mathrm{M}$ ) $200 \mathrm{D}, \mathrm{L}-\mathrm{APV}, 1 \mathrm{TTX}, 100$ picrotoxin at $32^{\circ} \mathrm{C}$ ] with whole-cell voltage clamp. Withdrawal of D,L-APV significantly increased the frequency of mEPSCs (from $0.87 \pm 0.15$ to $2.1 \pm 0.28$ responses $/ 200 \mathrm{msec} ; p<0.01 ; n 1=12$, 

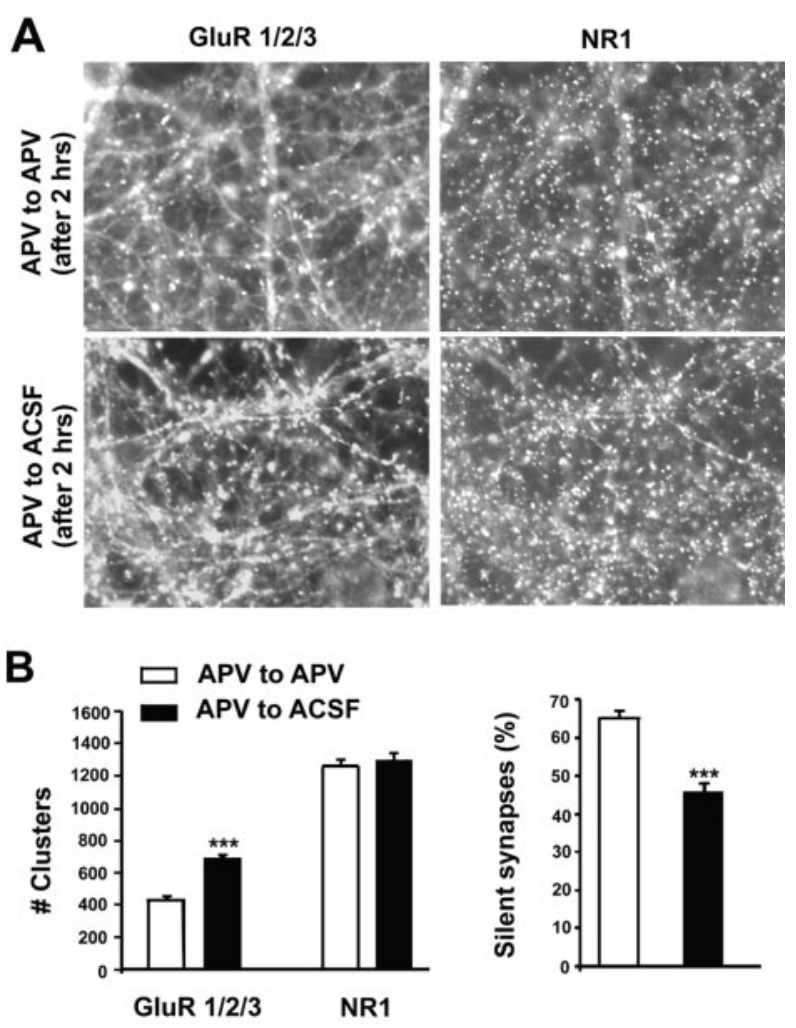

Figure 4. Changes in synaptic AMPA receptors induced by the withdrawal of D,L-APV can persist for at least $2 \mathrm{hr}$. $A$, Double staining of high-density cultured cortical neurons by antibodies against NR1 subunits and GluR1 subunits after these neurons were incubated in aCSF in the presence (top) and absence (bottom) of D, L-APV for $\sim 15-20 \mathrm{~min}$ and then returned to culture medium with D,L-APV for $2 \mathrm{hr}$. $B$, An increase in the number of AMPA clusters (left) and a decrease in the proportion of silent synapses (right) can persist for $2 \mathrm{hr}$ after the withdrawal of D,L-APV. ${ }^{* * *} p$ $<0.001$.

$n 2=12$; Fig. $7 A, B)$, although it had a negligible effect on the mean peak amplitude (from $12.3 \pm 0.6$ to $12.1 \pm 0.7 \mathrm{pA} ; p>0.05$; Fig. $7 C$ ), rise time (from $2.4 \pm 0.1$ to $2.5 \pm 0.1 \mathrm{msec} ; p>0.05$ ), and decay time (from $8.9 \pm 0.5$ to $8.9 \pm 0.4 \mathrm{msec} ; p>0.05$; Fig. $7 C$ ). In the presence of TTX the withdrawal of D,L-APV no longer had any obvious effect on the frequency of mEPSCs (from $1.1 \pm 0.25$ to $0.93 \pm 0.11$ responses $/ 200 \mathrm{msec} ; p>0.05 ; n 1=6$, $n 2=6$; Fig. $7 B$ ). In aCSF with $0 \mathrm{mM} \mathrm{Ca}^{2+}$ the withdrawal of D,L-APV also had no significant effect on the frequency of mEPSCs (from $0.87 \pm 0.14$ to $0.84 \pm 0.12$ responses $/ 200 \mathrm{msec}$; $p>0.05 ; n 1=9, n 2=9$; Fig. $7 B)$. These results suggest that silent synapses can acquire AMPA receptor-mediated responses after the activation of NMDA receptors by the spontaneous synaptic activity. Although we did not detect a significant change in the mean amplitude of mEPSCs after D,L-APV removal, the distribution of the mEPSC amplitudes shifted and contained higher percentages of large $(>30 \mathrm{pA})$ and small $(<10 \mathrm{pA})$ mEPSC responses (Fig. $7 D$ ).

Many previous reports have indicated that CaM-dependent kinase II plays a critical role in the induction of LTP (Silva et al., 1992; Giese et al., 1998; Soderling and Derkach, 2000). Recent studies also have shown that CaM kinase II is recruited rapidly to synapses after LTP induction in hippocampal slices (Ouyang et al., 1997, 1999; Shen and Meyer, 1999), where it phosphorylates the AMPA receptor GluR1 subunit of the AMPA receptor (Barria et al., 1997b; Lee et al., 2000). To examine whether similar
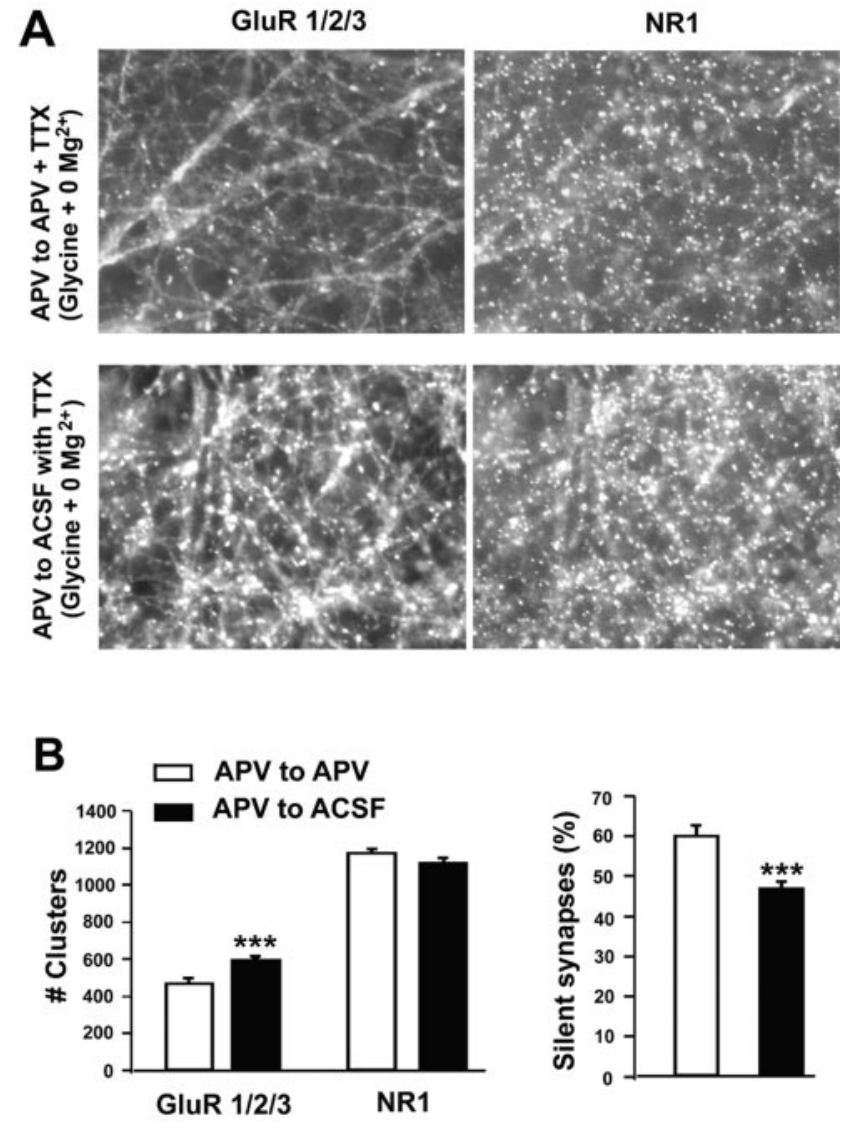

Figure 5. Mobilization of AMPA receptors can be induced in the presence of TTX in D,L-APV-treated high-density cortical neurons. $A$, Double staining of NMDA receptor subunits (NR1) and AMPA receptor subunits $(G l u R 1 / 2 / 3)$ in neurons that had been incubated in aCSF (with $1 \mu \mathrm{M}$ TTX, $100 \mu \mathrm{M}$ glycine, and no added $\mathrm{Mg}^{2+}$ ) in the presence (top) and absence (bottom) of D,L-APV. B, The addition of glycine and the withdrawal of $\mathrm{Mg}^{2+}$ significantly increased the number of AMPA receptor clusters (left) and decreased the proportion of silent synapses even in the presence of TTX (right). ${ }^{* * *} p<0.001$.

processes occurred in the high-density cortical cultures, we analyzed the distribution of CaM kinase II and the phosphorylation of GluR1 before and after D,L-APV removal. Using immunocytochemical techniques with CaM kinase II antibodies, we found that, similar to LTP in hippocampal slices, the activation of NMDA receptors in cortical cultures induced a rapid mobilization of $\mathrm{CaM}$ kinase II to synapses (Fig. $8 A, B$ ). In contrast, no corresponding increase was observed in the control cultures maintained in D,L-APV (Fig. 8A,B). Moreover, using Western blot techniques with a phosphorylation site-specific antibody against the major CaM kinase II site on GluR1 (serine 831), we found that phosphorylation of serine 831 was significantly increased in total cell extracts $(0.227 \pm 0.010$ to $0.418 \pm 0.034 ; p<$ $0.005 ; n 1=6, n 2=6$; Fig. $8 C, D)$. Interestingly, this increased phosphorylation occurred preferentially on surface receptors isolated with the use of surface biotinylation techniques (from $0.132 \pm 0.008$ to $0.317 \pm 0.028 ; p<0.001 ; n 1=6, n 2=6$; Fig. $8 E, F)$. Subtraction of the GluR1-S831-phospho surface signal from the GluR1 total reveals that, although phosphorylated at a basal level, there is only a small, but nonsignificant, increase in GluR1-S831 phosphorylation of intracellular AMPA receptors (from $0.336 \pm 0.137$ to $0.421 \pm 0.174 ; p>0.05 ; n 1=6, n 2=6$ ). Phosphorylation of GluR1 serine 845 was not detectable in these 
A
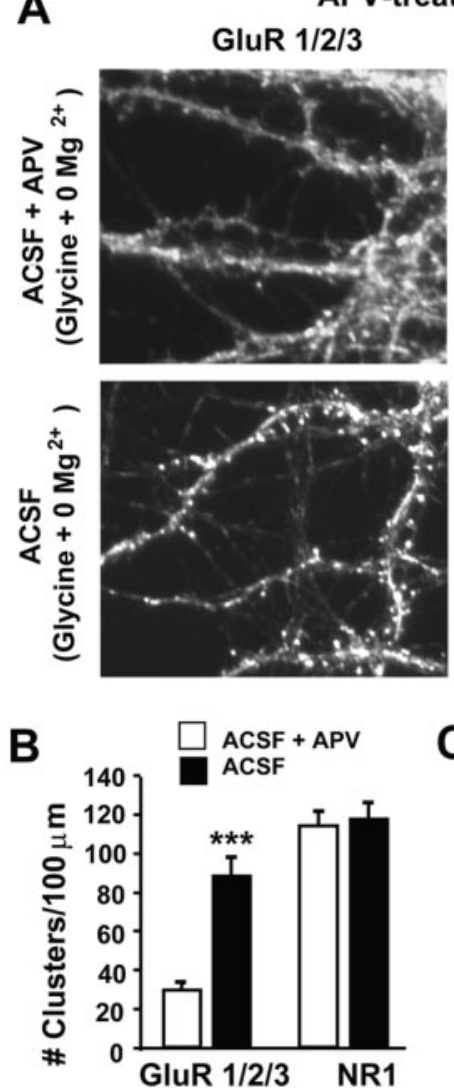

APV-treated Cultures
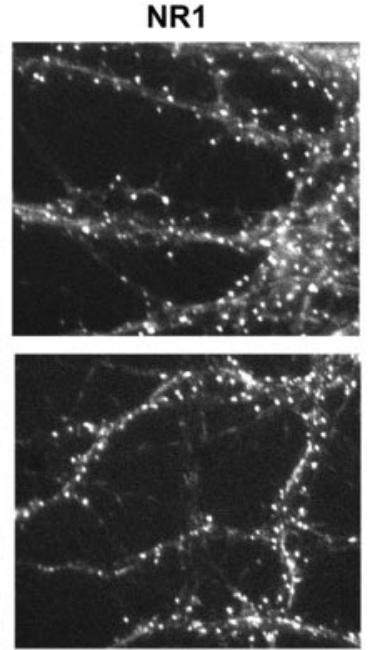

C

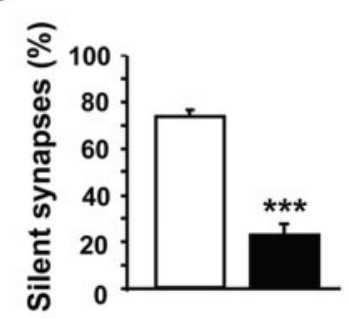

D

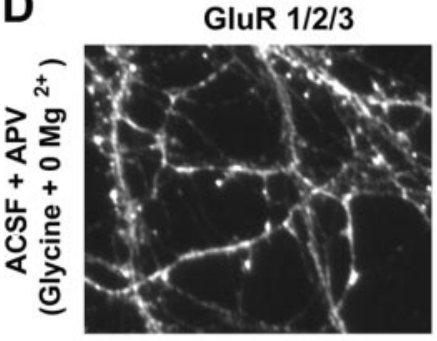

Untreated Cultures

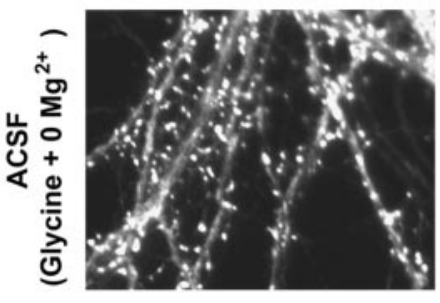

E

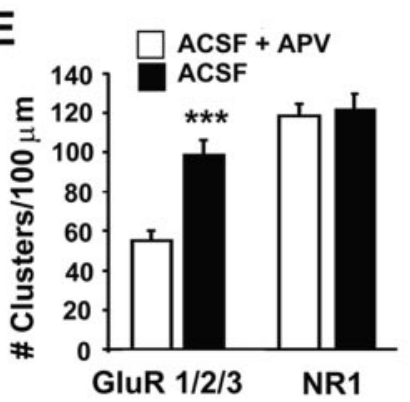

NR1
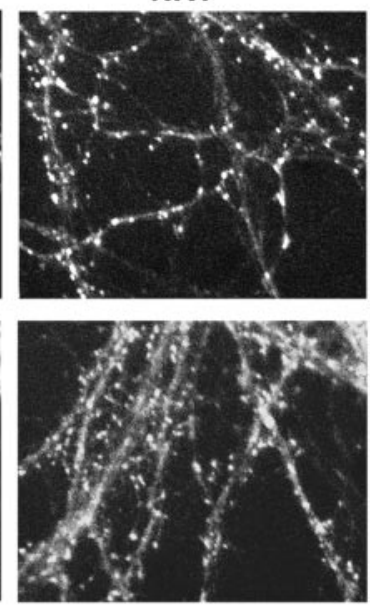

$\mathbf{F}$

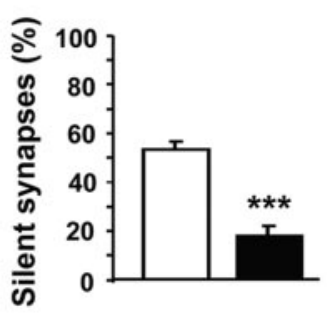

Figure 6. Rapid mobilization of AMPA receptors into silent synapses via the activation of NMDA receptors in low-density hippocampal cultures. $A$, Double staining of low-density hippocampal neurons that had been treated chronically with D,L-APV by antibodies against an NMDA receptor subunit (NR1) and AMPA receptor subunits (GluR1/2/3). Top two panels, A neuron that had been incubated in aCSF with $100 \mu \mathrm{M}$ glycine, $200 \mu \mathrm{M}$ D,L-APV, and no added $\mathrm{Mg}^{2+}$ for $15 \mathrm{~min}$. Bottom two panels, A neuron that had been incubated in similar aCSF without D,L-APV. $B$, The number of AMPA clusters was increased significantly via the activation of NMDA receptors by glycine and $0 \mathrm{Mg}^{2+} . C$, The proportion of silent synapses was decreased significantly via the activation of NMDA receptors. $D-F$ are similar to $A-C$, with the use of neurons that had been grown in culture medium in the absence of D,L-APV. Open bars, Neurons that had been incubated in aCSF containing glycine, D,L-APV, and no added $\mathrm{Mg}^{2+}$; filled bars, neurons that had been incubated in aCSF containing glycine, no D,L-APV, and no added $\mathrm{Mg}^{2+}$.*** $p<0.001$.

experiments (data not shown). These results demonstrate that the activation of NMDA receptors by spontaneous activity in cultured cortical neurons can induce coincident and rapid translocation of AMPA receptors and CaM kinase II to synapses and increased CaM kinase II phosphorylation of the GluR1 AMPA receptor subunit.

\section{DISCUSSION}

Changes in AMPA receptor-mediated responses have been proposed to be important to various forms of synaptic plasticity, including LTP and LTD (Raymond et al., 1993; Kim and Huganir, 1999; Turrigiano, 2000). Electrophysiological studies have reported that a significant proportion of synapses in the CNS contains NMDA receptor responses, but no AMPA receptor responses (Isaac et al., 1995; Liao et al., 1995; Durand et al., 1996). Such synapses would be functionally silent at normal resting membrane potentials because of the voltage-dependent blockade of NMDA receptors by $\mathrm{Mg}^{2+}$ (Mayer et al., 1984; Nowak et al., 1984). These silent synapses progressively become active via the acquisition of AMPA receptor-mediated responses during neuronal development and can be activated rapidly during LTP (Isaac et al., 1995; Liao et al., 1995; Durand et al., 1996; Wu et al., 1996). Recent evidence has suggested that the activation of AMPA receptor responses is attributable to rapid changes in the level of synaptic AMPA receptors (Shi et al., 1999; Hayashi et al., 2000). In these previous studies it was shown that recombinant GFP-tagged GluR1 subunits expressed in organotypic hippocampal slices can be recruited to synapses by LTP-inducing stimuli (Shi et al., 1999; Hayashi et al., 2000). In this current study we combined immunocytochemical, biochemical, and electrophysiological techniques to study the NMDA receptor-dependent synaptic delivery of native AMPA receptor subunits in both highdensity cortical and low-density hippocampal neuronal cultures. We predicted that high levels of spontaneous synaptic activity in cortical neuronal cultures might be able to activate NMDA receptors in a way similar to tetanus stimulation, a method often used to induce LTP. To increase the number of silent synapses in our cultures, we chronically treated the cultures with D,L-APV, starting at a very early stage of in vitro development. Similar to our previous studies in low-density hippocampal cultures, D,LAPV treatment produced a large proportion of silent synapses in these high-density cortical cultures (Rao and Craig, 1997; Liao et al., 1999). After the withdrawal of D,L-APV the vast majority of dendrites that previously contained diffusely distributed AMPA receptors rapidly acquired clustered AMPA receptors. Withdrawal of D,L-APV also induced a parallel increase in the frequency of mEPSC responses. A blockade of spontaneous activity 

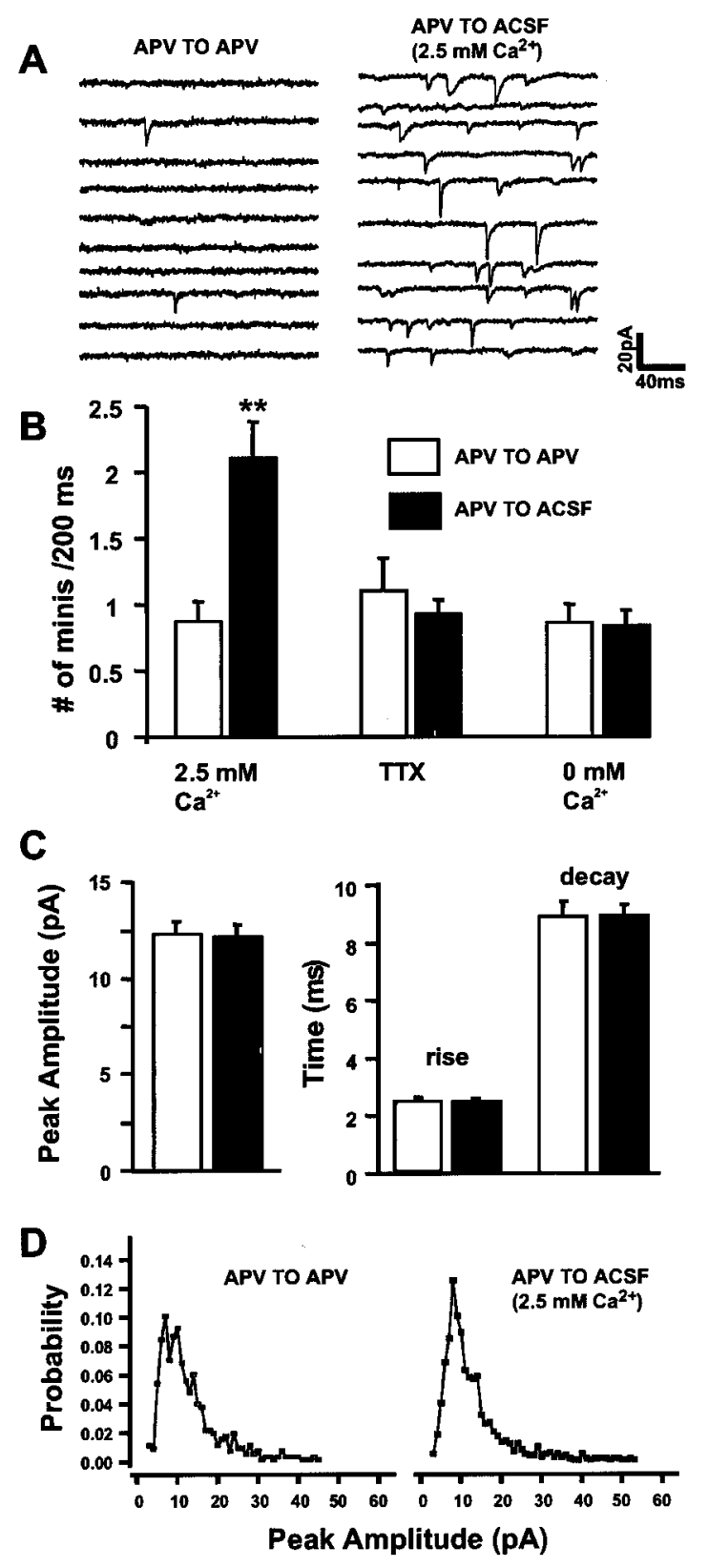

Figure 7. Withdrawal of D,L-APV significantly increased the frequency of mEPSC responses. A, Left, Ten representative consecutive traces recorded from a neuron after 15 min of incubation in aCSF in the presence of D,L-APV. A, Right, Ten similar traces after incubation in aCSF in the absence of D,L-APV. B, Withdrawal of D,L-APV significantly increased the frequency of mEPSC responses ( filled bars) compared with control (open bars). TTX and $0 \mathrm{mM} \mathrm{Ca}{ }^{2+}$ blocked this increase. $C$, Withdrawal of D,L-APV had a negligible effect on the peak amplitude (left) and the rise time and decay time (right) of EPSC responses. $D$, The probability of mEPSC responses over a wide range of peak amplitudes. In all, 50 consecutive sweeps were selected from each recorded neuron and pooled to calculate the probability for mEPSC responses occurring at each $1 \mathrm{pA}$ interval of peak amplitude. ${ }^{* *} p<0.01$.

by TTX or $0 \mathrm{~mm} \mathrm{Ca}^{2+}$ prevented this synaptic delivery of AMPA receptors. These results indicate that the high levels of spontaneous synaptic activity in high-density cortical cultures can induce a rapid NMDA receptor-dependent mobilization of AMPA receptors into silent synapses. In addition, we found that we could circumvent the low level of spontaneous activity in low-density hippocampal cultures and rapidly recruit AMPA receptors to synapses by activating NMDA receptors via the removal of D,LAPV and $\mathrm{Mg}^{2+}$ in the presence of glycine. Our results are similar to a recent study published after the completion of this work, showing NMDA receptor-dependent synaptic insertion of AMPA receptors in cultured dissociated hippocampal neurons (Lu et al., 2001).

Interestingly, the redistribution of AMPA receptors in these cultures is remarkably similar to the recently reported change of GFP-tagged GluR1 subunits induced by a tetanus stimulation in organotypic hippocampal slices (Shi et al., 1999). This similarity suggests that the redistribution of AMPA receptors in these two systems may be induced by similar cellular processes. In this study we further demonstrated that these newly acquired AMPA receptor clusters were located in synapses that were labeled by antibodies against NMDA receptor NR1 subunits and synaptophysin. This indicates that the previously silent synapses in these cultures were activated by the recruitment of native AMPA receptors. These data provide additional direct evidence that the activation of silent synapses may mediate, in part, the long-term potential of synaptic transmission.

Previous studies have demonstrated that the GluR1 subunit is a substrate for CaM kinase II, PKC, and PKA (Roche et al., 1996; Barria et al., 1997b; Mammen et al., 1997) and that phosphorylation of the GluR1 subunit can increase AMPA receptor ion channel function (McGlade-McCulloh et al., 1993; Roche et al., 1996; Barria et al., 1997a,b; Benke et al., 1998; Derkach et al., 1999). Recent studies in hippocampal slices have suggested that the modulation of AMPA receptor ion channel properties by protein phosphorylation may be important in LTP and LTD (Soderling and Derkach, 2000). It has been reported that LTP induction in slice preparations or glutamate treatment of neuronal cultures induces the rapid recruitment of CaM kinase II to excitatory synapses (Ouyang et al., 1997, 1999). Moreover, LTP induction increases CaM kinase II phosphorylation of serine 831 on the GluR1 subunit (Barria et al., 1997a; Banke et al., 2000; Lee et al., 2000). As seen in these LTP studies in hippocampal slices, we also observed a rapid synaptic targeting of CaM kinase II and an increase in GluR1-S831 phosphorylation. This phosphorylation and its effect on channel kinetics may account in part for the observed changes in the distribution of mEPSC amplitudes, but it is not clear whether the synaptic delivery of AMPA receptors and the changes in mEPSC frequency require the phosphorylation of serine 831 . It is certainly possible that phosphorylation of this site regulates synaptic trafficking of the AMPA receptor in addition to regulating channel function. However, the regulation of synaptic recruitment of AMPA receptors may be via a distinct mechanism, which occurs in concert with and complements the modification of channel properties. The molecular and cellular mechanisms that regulate the mobilization of AMPA receptors into postsynaptic silent synapses are still not clear. Studies in several laboratories have suggested that proteins that interact with AMPA receptor subunits, such as the PDZ-containing proteins GRIP1/2/ABP, PICK1, and SAP97 as well as membrane fusion factor NSF, may regulate the function of AMPA receptors (Dong et al., 1997, 1999; Nishimune et al., 1998; Osten et al., 1998; Song et al., 1998; Li et al., 1999; Noel et al., 1999; Hayashi et al., 2000). Future studies will be needed to elucidate the role of these proteins in LTP and the mechanism for the coupling of $\mathrm{CaM}$ kinase II activation to the regulation of AMPA receptor distribution. 

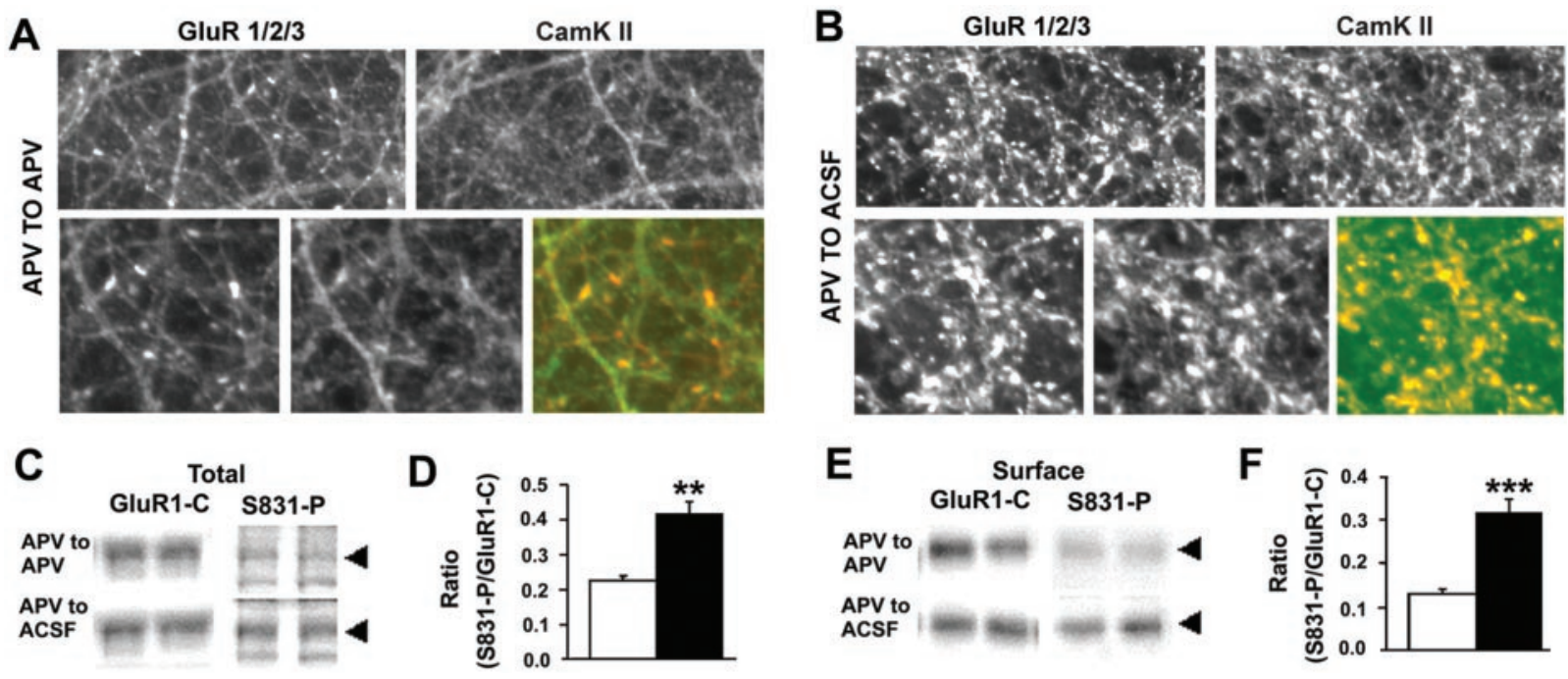

Figure 8. CaM kinase II is mobilized rapidly into synapses, and phosphorylation of GluR1-S831 is upregulated in response to the synaptic targeting of AMPA receptors. $A, B$, Double staining of high-density cultured cortical neurons by antibodies against AMPA receptor subunits $(G l u R 1 / 2 / 3)$ and an antibody against CaM kinase II (CaMK II ) after the neurons were incubated in aCSF in the presence $(A)$ and absence $(B)$ of D,L-APV. Bottom panels in $A$ and $B$ show enlarged images ( $2 \times$ ) of GluR1/2/3 (left), CaMK II (middle), and overlay of GluR1/2/3 (red) and CaMK II (green). $C$, Representative immunoblots of total proteins (in duplicate) immunoblotted with either anti-GluR1-C or anti-GluR-S831-P from control (D,L-APV to D,L-APV) and experimental (D,L-APV to aCSF) conditions. D, Quantitative analysis of immunoblots comparing the relative ratio of anti-GluR-S831-P immunostaining with anti-GluR1-C ( $y$-axis) from control and experimental conditions. $E$, Similar blots as in $C$, but depicting two representative examples from isolated surface proteins. Arrowhead indicates the GluR1-S831-P band. F, Quantitative analysis of surface proteins comparing anti-GluR-S831-P with anti-GluR1-C ( $y$-axis). ${ }^{* *} p<0.01 ; * * p<0.001$.

\section{REFERENCES}

Banke TG, Bowie D, Lee H, Huganir RL, Schousboe A, Traynelis SF (2000) Control of GluR1 AMPA receptor function by cAMPdependent protein kinase. J Neurosci 20:89-102.

Banker GA, Cowan WM (1977) Rat hippocampal neurons in dispersed cell culture. Brain Res 126:397-442.

Barria A, Derkach V, Soderling T (1997a) Identification of the $\mathrm{Ca}^{2+}$ / calmodulin-dependent protein kinase II regulatory phosphorylation site in the $\alpha$-amino-3-hydroxyl-5-methyl-4-isoxazole-propionate-type glutamate receptor. J Biol Chem 272:32727-32730.

Barria A, Muller D, Derkach V, Griffith LC, Soderling TR (1997b) Regulatory phosphorylation of AMPA-type glutamate receptors by CaM-KII during long-term potentiation. Science 276:2042-2045.

Benke TA, Luthi A, Isaac JT, Collingridge GL (1998) Modulation of AMPA receptor unitary conductance by synaptic activity. Nature 393:793-797.

Bliss TV, Collingridge GL (1993) A synaptic model of memory: longterm potentiation in the hippocampus. Nature 361:31-39.

Carroll RC, Lissin DV, von Zastrow M, Nicoll RA, Malenka RC (1999) Rapid redistribution of glutamate receptors contributes to long-term depression in hippocampal cultures. Nat Neurosci 2:454-460.

Davies SN, Lester RAJ, Reymann KG, Collingridge GL (1989) Temporally distinct pre- and postsynaptic mechanisms maintain long-term potentiation. Nature 338:500-503.

Derkach V, Barria A, Soderling TR (1999) $\mathrm{Ca}^{2+} /$ calmodulin-kinase II enhances channel conductance of $\alpha$-amino-3-hydroxy-5-methyl-4isoxazolepropionate-type glutamate receptors. Proc Natl Acad Sci USA 96:3269-3274

Dong H, O'Brien RJ, Fung ET, Lanahan AA, Worley PF, Huganir RL (1997) GRIP: a synaptic PDZ domain-containing protein that interacts with AMPA receptors. Nature 386:279-284.

Dong H, Zhang P, Liao D, Huganir RL (1999) Characterization, expression, and distribution of GRIP protein. Ann NY Acad Sci 868:535-540.

Durand G, Kovalchuk Y, Konnerth A (1996) Long-term potentiation and functional synapse induction in developing hippocampus. Nature 381:71-75.

Erondu NE, Kennedy MB (1985) Regional distribution of type $\mathrm{II} \mathrm{Ca}^{2+} /$ calmodulin-dependent protein kinase in rat brain. $\mathrm{J}$ Neurosci 5:3270-3277

Ghosh A, Greenberg ME (1995) Distinct roles for bFGF and NT-3 in the regulation of cortical neurogenesis. Neuron 15:89-103.

Giese KP, Fedorov NB, Filipkowski RK, Silva AJ (1998) Autophosphorylation at Thr286 of the $\alpha$-calcium/calmodulin kinase II in LTP and learning. Science 279:870-873.

Hayashi Y, Shi SH, Esteban JA, Piccini A, Poncer JC, Malinow R (2000) Driving AMPA receptors into synapses by LTP and CaMKII: requirement for GluR1 and PDZ domain interaction. Science 287:2262-2267.
Hollmann M, Heinemann S (1994) Cloned glutamate receptors. Annu Rev Neurosci 17:31-108.

Isaac JT, Nicoll RA, Malenka RC (1995) Evidence for silent synapses: implications for the expression of LTP. Neuron 15:427-434.

Katz LC, Shatz CJ (1996) Synaptic activity and the construction of cortical circuits. Science 274:1133-1138.

Kauer JA, Malenka RC, Nicoll RA (1988) A persistent postsynaptic modification mediates long-term potentiation in the hippocampus. Neuron 1:911-917.

Kim JH, Huganir RL (1999) Organization and regulation of proteins at synapses. Curr Opin Cell Biol 11:248-254.

Lee HK, Kameyama K, Huganir RL, Bear MF (1998) NMDA induces long-term synaptic depression and dephosphorylation of the GluR1 subunit of AMPA receptors in hippocampus. Neuron 21:1151-1162.

Lee HK, Barbarosie M, Kameyama K, Bear MF, Huganir RL (2000) Regulation of distinct AMPA receptor phosphorylation sites during bidirectional synaptic plasticity. Nature 405:955-959.

Li P, Kerchner GA, Sala C, Wei F, Huettner JE, Sheng M, Zhuo M (1999) AMPA receptor-PDZ interactions in facilitation of spinal sensory synapses. Nat Neurosci 2:972-977.

Liao D, Jones A, Malinow R (1992) Direct measurement of quantal changes underlying long-term potentiation of CA1 hippocampus. Neuron 9:1089-1097.

Liao D, Hessler NA, Malinow R (1995) Activation of postsynaptically silent synapses during pairing-induced LTP in CA1 region of hippocampal slice. Nature 375:400-404

Liao D, Zhang X, O’Brien R, Ehlers MD, Huganir RL (1999) Regulation of morphological postsynaptic silent synapses in developing hippocampal neurons. Nat Neurosci 2:37-43.

Lissin DV, Gomperts SN, Carroll RC, Christine CW, Kalman D, Kitamura M, Hardy S, Nicoll RA, Malenka RC, von Zastrow M (1998) Activity differentially regulates the surface expression of synaptic AMPA and NMDA glutamate receptors. Proc Natl Acad Sci USA 95:7097-7102.

Lissin DV, Carroll RC, Nicoll RA, Malenka RC, von Zastrow M (1999) Rapid, activation-induced redistribution of ionotropic glutamate receptors in cultured hippocampal neurons. J Neurosci 19:1263-1272.

Lu W, Man H, Ju W, Trimble WS, MacDonald JF, Wang YT (2001) Activation of synaptic NMDA receptors induces membrane insertion of new AMPA receptors and LTP in cultured hippocampal neurons. Neuron 29:243-254.

Malenka RC (1994) Synaptic plasticity in the hippocampus: LTP and LTD. Cell 78:535-538.

Mammen AL, Huganir RL, O’Brien RJ (1997) Redistribution and stabilization of cell surface glutamate receptors during synapse formation. J Neurosci 17:7351-7358.

Mayer ML, Westbrook GL, Guthrie PB (1984) Voltage-dependent block 
by $\mathrm{Mg}^{2+}$ of NMDA responses in spinal cord neurones. Nature 309:261-263.

McGlade-McCulloh E, Yamamoto H, Tan S-E, Brickey DA, Soderling TR (1993) Phosphorylation and regulation of glutamate receptors by calcium/calmodulin-dependent protein kinase II. Nature 362:640-642.

Muller D, Joly M, Lynch G (1988) Contributions of quisqualate and NMDA receptors to the induction and expression of LTP. Science 242:1694-1697.

Murphy TH, Blatter LA, Wier WG, Baraban JM (1992) Spontaneous synchronous synaptic calcium transients in cultured cortical neurons. J Neurosci 12:4834-4845.

Nishimune A, Isaac JT, Molnar E, Noel J, Nash SR, Tagaya M, Collingridge GL, Nakanishi S, Henley JM (1998) NSF binding to GluR2 regulates synaptic transmission. Neuron 21:87-97.

Noel J, Ralph GS, Pickard L, Williams J, Molnar E, Uney JB, Collingridge GL, Henley JM (1999) Surface expression of AMPA receptors in hippocampal neurons is regulated by an NSF-dependent mechanism. Neuron 23:365-376.

Nowak L, Bregestovski P, Ascher P, Herbet A, Prochiantz A (1984) Magnesium gates glutamate-activated channels in mouse central neurones. Nature 307:462-465.

Nusser Z, Luj $\leftrightarrow$ n R, Laube G, Roberts JD, Molnar E, Somogyi P (1998) Cell type and pathway dependence of synaptic AMPA receptor number and variability in the hippocampus. Neuron 21:545-559.

O'Brien RJ, Kamboj S, Ehlers MD, Rosen KR, Fischbach GD, Huganir RL (1998) Activity-dependent modulation of synaptic AMPA receptor accumulation. Neuron 21:1067-1078.

Osten P, Srivastava S, Inman GJ, Vilim FS, Khatri L, Lee LM, States BA, Einheber S, Milner TA, Hanson PI, Ziff EB (1998) The AMPA receptor GluR2 C terminus can mediate a reversible, ATP-dependent interaction with NSF and $\alpha$ - and $\beta$-SNAPs. Neuron 21:99-110.

Ouyang Y, Kantor D, Harris KM, Schuman EM, Kennedy MB (1997) Visualization of the distribution of autophosphorylated calcium/ calmodulin-dependent protein kinase II after tetanic stimulation in the CA1 area of the hippocampus. J Neurosci 17:5416-5427.

Ouyang Y, Rosenstein A, Kreiman G, Schuman EM, Kennedy MB (1999) Tetanic stimulation leads to increased accumulation of $\mathrm{Ca}^{2+}$ calmodulin-dependent protein kinase II via dendritic protein synthesis in hippocampal neurons. J Neurosci 19:7823-7833.

Petralia RS, Esteban JA, Wang YX, Partridge JG, Zhao HM, Wenthold RJ, Malinow R (1999) Selective acquisition of AMPA receptors over postnatal development suggests a molecular basis for silent synapses. Nat Neurosci 2:31-36.

Rao A, Craig M (1997) Activity regulates the synaptic localization of the NMDA receptor in hippocampal neurons. Neuron 19:801-812.

Raymond LA, Blackstone CD, Huganir RL (1993) Phosphorylation of amino acid neurotransmitter receptors in synaptic plasticity. Trends Neurosci 16:147-153.

Roche KW, O'Brien RJ, Mammen AL, Bernhardt J, Huganir RL (1996) Characterization of multiple phosphorylation sites on the AMPA receptor GluR1 subunit. Neuron 16:1179-1188.

Shen K, Meyer T (1999) Dynamic control of CaMKII translocation and localization in hippocampal neurons by NMDA receptor stimulation. Science 284:162-166.

Shi SH, Hayashi Y, Petralia RS, Zaman SH, Wenthold RJ, Svoboda K, Malinow R (1999) Rapid spine delivery and redistribution of AMPA receptors after synaptic NMDA receptor activation. Science 284:1811-1816

Silva AJ, Paylor R, Wehner JM, Tonegawa S (1992) Deficient hippocampal long-term potentiation in $\alpha$-calcium/calmodulin kinase II mutant mice. Science 257:206-209.

Soderling TR, Derkach VA (2000) Postsynaptic protein phosphorylation and LTP. Trends Neurosci 23:75-80.

Song I, Kamboj S, Xia J, Dong H, Liao D, Huganir RL (1998) Interaction of the $N$-ethylmaleimide-sensitive factor with AMPA receptors. Neuron 21:393-400.

Turrigiano GG (2000) AMPA receptors unbound: membrane cycling and synaptic plasticity. Neuron 26:5-8.

Turrigiano GG, Leslie KR, Desai NS, Rutherford LC, Nelson SB (1998) Activity-dependent scaling of quantal amplitude in neocortical neurons. Nature 391:892-896.

Wu G, Malinow R, Cline HT (1996) Maturation of a central glutamatergic synapse. Science 274:972-976. 